\title{
OPTIMIZATION OF CARBOPOL 940 AND OLEIC ACID IN DICLOFENAC SODIUM BASE GEL USING FACTORIAL DESIGN $2^{2}$ METHOD
}

\author{
${ }^{1}$ Eka Diana Rahmawati, ${ }^{2}$ Weka Sidha Bhagawan, and ${ }^{2}$ Fidia Rizkiah \\ ${ }^{1}$ Student of Department of Pharmacy, Faculty of Medical and Health Sciences, Maulana Malik Ibrahim State \\ Islamic University \\ Jl. Gajayana No. 50 Malang 65144 \\ ${ }^{2}$ Department of Pharmacy, Faculty of Medical and Health Sciences, Maulana Malik Ibrahim State Islamic \\ University \\ Jl. Gajayana No. 50 Malang 65144 \\ * Corresponding author, email: wekabhagawan@farmasi.uin-malang.ac.id \\ Co-author, email: fidia_rizkiah@yahoo.com \\ Co-author, email: eka.diana659@gmail.com
}

\begin{abstract}
The aim of the present study was to determine the effect of carbopol 940, oleic acid and interaction of both in the value of viscosity and release rate and to find optimum formula of diclofenac sodium base gel which can produced viscoisity between $20 \mathrm{dPa} . \mathrm{s}-200 \mathrm{dPa} . \mathrm{s}$ and rate release $50 \mu \mathrm{g} / \mathrm{cm}^{2}$. menit ${ }^{1 / 2}-150 \mu \mathrm{g} / \mathrm{cm}^{2}$. menit ${ }^{1 / 2}$ using factorial design $2^{2}$. The level of carbopol 940 were 1,3\% and 0,8\% while the level of oleic acid were 5\% and 20\%. Analysis of the research used Design Expert 10 software.The results showed that carbopol 940 and oleic acid had significant effect in determining the viscosity response and the release rate. The addition of carbopol 940 and oleic acid l increased the viscosity response and the addition of carbopol 940 and oleic acid decreased the release flux response. There were 100 optimum compositions of combination of carbopol 940 between $0.8 \%$ to $1,194 \%$ and oleic acid between $5 \%$ and $19.95 \%$ which can be used to obtain sodium diclofenac base gel preparation with viscosity responses between 76,042 dPa.s -199,570 dPa.s and flux release responses from 101,000 $\mu \mathrm{g} / \mathrm{cm}^{2}$. minute ${ }^{1 / 2}$ until 124,250 $\mathrm{g} / \mathrm{cm}^{2}$. minute $e^{1 / 2}$.
\end{abstract}

Keyword : carbopol 940, diclofenac sodium gel, factorial design, oleic acid.

\section{INTRODUCTION}

Sodium is a non-steroid drug low soluble in water, and having excellent antiinflammatory and analgesic effects. At the present time, it is used only in the form of oral preparations or suppositories exhibiting excellent anti-inflammatory and analgetic effects when so administered. However, side effects such as stomach and intestine problems, liver problems and kidney problems may occur, especially upon oral administration [1]. It also have 50\% First Past Effect (FPE) in the liver and irritating the GI-tract [2]. Topical delivery 
system are appropriate to attent that. Diclofenac sodium base gel have in-vitro rate release more good then in other such topical delivery as cream and ointment [3]. Further, gels for dermatological use have several favorable properties such as being thixotropic, greaseless, easily spreadable, easily removable, emollient, nonstaining, compatible with several excipients, and water-soluble or miscible [4]. The necessary excipient for a gel is gelling agent that carbopol 940 are suitable cause It biocompatible and biodegradable for diclofenac sodium [1].

Diclofenac sodium is categorized into Biopharmaceutical Classification System (BCS) class $2^{\text {nd }}$. It has 13,4 in coeffision partition [2]. Meaning diclofenac sodium low soluble in water and high soluble in oil. So that, it is not good to penetrate in skin with gel administration almost the water. Suitable enhancer must be added to solve diclofenac sodium in gel and to increase penetration on the skin. Oleic acid match with diclofenac sodium because it can enhance sodium diklofenac more then other enhance such isopropyl miristat as castor oil, olive oil and isopropyl palmintat [5].

The goal of this research are to know impact of carbopol 940 and oleic acid and interaction of both to the value of viscosity and rate release and to find the optimum formula of carbopol 940 and oleic acid based on viscosity and rate release are appropriate using factorial design factorial $2^{2}$ with Design Expert version 10 software. The respons of viscosity are between $20 \mathrm{dPa}$.s - $200 \mathrm{dPa} . \mathrm{s}$ and rate release responses from $50 \mu \mathrm{g} / \mathrm{cm}^{2}$.minute ${ }^{1 / 2}$ until $150 \mu \mathrm{g} / \mathrm{cm}^{2} \cdot$ minute $^{1 / 2}$.

\section{MATERIAL AND METHOD}

\section{Materials}

The material are diclofenac sodium as active ingredients, gelling agent carbopol 940 (Sumutomo Seika Chemicals), enhancer oleic acid (Avantor), tween 80 as emulsifying agent, propyl paraben and metyl paraben added as preservative and TEA as alkalizing agent.

\section{Instrumentation}

The Instrumens are bekker glass, mortar, stamper, stainless steel bowl, analytical scales, water bath, stopwatch, spread modification instrument, viscotester (Viscometer Brookfield), pH meter (Denver), hot plate, spectrophotometer UV-Vis (Shimadzu UV-1800), dissolution tester (Erweka DT-700), membrane cellophane, thermometer, ultrasonic, SPSS software dan Design Expert 10 software. 


\section{Procedure}

\section{Orientation level of each factor}

Formula in this research based on factorial design formula $2^{2}$ that have two factors are carbopol 940 and oleic acid and two level are low level (-1) and high level (+1) in each factor (table 1). The low level of carbopol 940 is $0,8 \%$ and high level is $1,3 \%$. Further, oleic acid are $5 \%$ in low level and $20 \%$ in high level. The composition and concentration of diclofenac sodium base gel is in the table 2 .

\section{Procedure of gel preparation}

Carbopol 940 is dispersed in aquadest (1 gram of carbopol 940 is dirpersed in $20 \mathrm{ml}$ of aquadest) and let stand that on night. Add TEA to neutralize carbopol 940 and until seen transparant as gel. In the other, mix oleic acid and tween 80 and stir until homogen. Mix both mixture and add sodium diklofenac, propyl paraben, metyl paraben and aquades. Stiring the end mixture is until homogen.

\section{Evaluation of gel}

Organoleptic test for evaluation gel are colour, smelling and homogenity by surface of blass. Other test are $\mathrm{pH}$ test using $\mathrm{pH}$ meter instrument and spred test making two mirror. For spread test, put 1 gram of gel into surface of mirror and put other mirror and others having total of both 125 gram on the gel.

\section{Viscosity test}

50 gram gel diclofenac sodium was tested using viscometer Brookfield. Spindle.The required value of viscosity are between $20 \mathrm{dPa} . \mathrm{s}$ - $200 \mathrm{dPa}$.s because this viscosity can spread well and comfortably to its wearer [6].

\section{Rate release test}

Membrane cellophane rinse with buffer phosphate $\mathrm{pH} 7,4 \pm 0,05$ during \pm 12 hours. The diffusion instrumen is prepared with $500 \mathrm{ml}$ buffer phosphate $\mathrm{pH} 7,4 \pm 0,05$ in the chamber (receptor compartement). 1 gram sample (gel) is plased in cakram and is closed with membrane cellophane (donor compartement). The diffusion cell is maintained at $37^{\circ} \mathrm{C}$ and the solution in the receptor chamber is stirred continuously at $100 \mathrm{rpm}$. At 0, 5, 15, 30, 45, 60, $90,120,150,180$, and 240 minutes, $5 \mathrm{ml}$ of the solution is removed from receptor compartment and replaced immediately with an equal proportions of fresh buffer phosphate. The samples are analyzed in UV - Visible spectrophotometer after suitable dilutio. Flux 
release is the slope from regresion linier the cumulative amount of sodium diclofenac vs $\sqrt{\text { times }}$ in steady state condition.

\section{RESULTS AND DISCUSSION}

\section{Evaluation of gel}

All of the formula had white colour and having aroma like an oleic acid. All developed gels showed good homogeneity with absence of lumps. The $\mathrm{pH}$ of all the four formulations were in the range of 6,48 to 6,53 that suits the skin $\mathrm{pH}$, indicating skin compatibility. Then, the spreadability of formulations ranged from 5,53 to $6,83 \mathrm{~cm}$. The values of spreadability indicate that the gel is easily spreadable with minimal of shear.

\section{Viscosity}

The viscosity of all the four formulations ranged from 75,83 to $230,83 \mathrm{dPa}$.s. Gels with high viscosity do not easily extrude from the tube whereas, low viscous gels may flow quickly and hence suitable viscosity is required to extrude a gel. Carbopol 940 and oleic acid had positive effect to gel viscosity. It mean that addition of carbopol 940 and oleic acid would increased the viscosity of gel. Carbopol 940 have biger effect that oleic acid to visosity value. It cause carbopol 940 having high viscosity $40.000-60.000 \mathrm{cp}$ [7]. The effect value was shown in table 3 and the contour plot $2 \mathrm{D}$ of factor effect also in figure 1.

\section{Release rate}

The flux of all the four formulations ranged from 94,15 to $124,25 \mu \mathrm{g} / \mathrm{cm}^{2}$.minute ${ }^{1 / 2}$. With increasing time, also increase the drug release from the gel. Carbopol 940 and oleic acid have negative effect to the flux (table 4). Increasing carbopol 940 and oleic acid would decreased the flux. It shown in contour plot 2D in figure 2. Blue area show the low value of flux while red area show the high value of flux.

Having rigid character, carbopol make the gel becomed thickness. This cause active ingredient having lipofil character difficult to leave the gel system then it penetrate the cellophane membrane. The function of oleic acid is an enhancer. It can enhance diclofenac sodium and increase rate release in appropriate amount [8]. This research may the appropriate amount in 5\% of oleic acid. Increasing enhancer oleic acid can decrease rate release of diclofenac sodium that cause too much of it and saturated in the gel system. So that will disturb the diclofenac sodium to exit and then permeate the cellophane membrane. 


\section{Optimization of carbopol 940 and oleic acid using design factorial $2^{2}$}

Factorial Design for two factors at two levels with -1 and +1 equivalent to a $2^{2}$ factorial design was chosen as the experimental design. This is an effective second-order experimental design associated with a minimum number of experiments to estimate the influence of individual variables (main effects) and their second-order effects. To investigate the factors systematically, a full factorial design was employed. The coded and actual factors was shown in table 5. The effect on vascosity(Y1) was observed to be significant by ANOVA and the polynomial equation was found as follows:

- $\quad$ Final equation in terms of coded factors: Y1 = 165,21 +77,29X1 + 11,88X2

- $\quad$ Final equation in terms of actual factors: $Y 1=-179,20833+309,16667 *$ carbopol 940 $+1,58333 *$ asam oleat

The positive sign for coefficient of X1 (carbopol 940) indicates that as carbopol 940 increases, viscosity increases. And also the positive sign for coefficient of X2 (oleic acid) indicates that as oleic acid increases, viscosity increases. The effect on release rate (Y2) was observed to be significant by ANOVA and the polynomial equation was found as follows:

- $\quad$ Final equation in terms of coded factors: $\mathrm{Y} 1=110,56-4,60 \mathrm{X} 1-10,45 \mathrm{X} 2-$ $1,36 \mathrm{X} 1 \mathrm{X} 2$

- $\quad$ Final equation in terms of actual factors: $Y 1=137,78787-9,34178 *$ carbopol 940 $0,63397 *$ asam oleat $-0,72364 *$ carbopol $940 *$ asam oleat

The negative sign for coefficient of X1(carbopol 940) indicates that as the carbopol 940 increases, the rate release (Y2) also increases. And also is same for sign in for coefficient of X2 (oleic acid).

There were 100 optimum composition combinations of carbopol 940 between $0.8 \%$ to $1,194 \%$ and oleic acid between $5 \%$ to $19.95 \%$ which can be used to obtain viscosity from $76,042 \mathrm{dPa} . \mathrm{s}-199,570 \mathrm{dPa} . \mathrm{s}$ and the flux from $101,000 \mu \mathrm{g} / \mathrm{cm}^{2} \cdot \mathrm{menit}^{1 / 2}-124,250$ $\mu \mathrm{g} / \mathrm{cm}^{2}$.menit ${ }^{1 / 2}$. That show in overlay plot on figure 3 . The optimum formula in yellow area.

\section{CONCLUSION}

It may be concluded that Factorial Design can be used for a systematic approach for designing and optimizing the desired formulation based on different process variables. Carbopol 940 and oleic acid have positive effect to viscosity and negative effect to rate release. With increasing carbopol 940 and oleic acid, the viscosity decreases while the rate 
release increases. The equation of coded factor or actual factor can be used to find the value of viscosity and rate release that you wanted.

\section{REFERENCES}

[1] Abrar B, Anis S, Tanu B and Singh S. Formulation and In-Vitro Evaluation Of NSAID's Gel. Int J Curr Pharm Res. 2012;4(3): 56-58.

[2] Sweetman, S.C. 2009. Martindale: The Complete Drug Reference. 36th Edition. London: Pharmaceutical Press

[3] Shah et al. 2009. In Vitro Release of Diclofenac Sodium From Different Topical Vehicles. Pharma Science Monitor An International Journal Of Pharmaceutical Sciences. Vol 2, Issue 2, Suppl 1: 31-39

[4] Sarisozen, C., Vural, I., Levchenko, T., Hincal, A. A., \& Torchilin, V. P. (2012). PEGPE-based micelles co-loaded with paclitaxel and cyclosporine A or loaded with paclitaxel and targeted by anticancer antibody overcome drug resistance in cancer cells. Drug Delivery, 19(4), 169-176

[5] Rao, Masthan CH.N.V.S., Reddy, Ram Bramha., Kumar. P, Raman. 2015. Formulation Development and Evaluation of Diclofenac Sodium Microemulsion. Indo American Journal of Pharmaceutical Sciences. IAJPS. Vol 2, No 12: 1673-1688

[6] Langenbucher and Lange. 2007. Reologi Farmasetik dalam Lachman, L., Lieberman, H.A., and Kanig, J.L. Teori dan Praktek Farmasi Industri II. Edisi III. Jakarta: Universitas Indonesia Press

[7] Rowe, R.C., Sheskey, P.J and Quinn, M.E. 2009. Handbook of Pharmaceutical Excipients, 6th Edition. Washington D.C: Pharmaceutical Press and American Pharmacists Association 2009

[8] Sinko, P. J. 2011. Farmasi Fisik dan Ilmu Farmasetika Edisi 5. Jakarta: EGC Kedokteran

Table 1. The formula based on design factorial $2^{2}$ method

\begin{tabular}{ccc}
\hline Name of & \multicolumn{2}{c}{ Factors } \\
\cline { 2 - 3 } formulas & Carbopol 940 & Oleic acid \\
\hline 1 & -1 & -1 \\
$\mathrm{a}$ & +1 & -1 \\
$\mathrm{~b}$ & -1 & +1 \\
$\mathrm{ab}$ & +1 & +1 \\
\hline
\end{tabular}


Table 2. Composition and concentration of sodium diclofenac base gel

\begin{tabular}{cccccc}
\hline Materials & Function & $\mathbf{1}(\mathbf{\%})$ & $\mathbf{a}(\mathbf{\%})$ & $\mathbf{b}(\mathbf{\%})$ & $\mathbf{a b}(\mathbf{\%})$ \\
\hline Sodium Diklofenac & $\begin{array}{c}\text { Active } \\
\text { ingredient }\end{array}$ & 1 & 1 & 1 & 1 \\
Carbopol 940 & $\begin{array}{c}\text { Gelling agent } \\
\text { Alkalizing } \\
\text { agent }\end{array}$ & 0,8 & 1,3 & 0,8 & 1,3 \\
TEA & $\begin{array}{c}\text { Enhancer } \\
\text { Emulsifying }\end{array}$ & 5 & 0,65 & 0,4 & 0,65 \\
Asam oleat & 2 & 2 & 2 & 20 \\
Tween 80 & $\begin{array}{c}\text { agent } \\
\text { Meservative }\end{array}$ & 0,18 & 0,18 & 0,18 & 0,18 \\
Propyl paraben & Preservative & 0,02 & 0,02 & 0,02 & 0,02 \\
Aquadest & & Ad 100 & Ad 100 & Ad 100 & Ad 100 \\
\hline
\end{tabular}

Table 3. Effect value of each factor and of both interaction to viscosity of gel

\begin{tabular}{cccc}
\hline Factors & $\begin{array}{c}\text { Value of } \\
\text { Effect }\end{array}$ & $\begin{array}{c}\boldsymbol{p} \text {-value } \\
\text { ANOVA }\end{array}$ & $\begin{array}{c}\text { Contribution } \\
(\%)\end{array}$ \\
\hline Carbopol 940 & 154,58 & $<0,0001$ & 97,44 \\
Oleic Acid & 23,75 & $<0,0001$ & 2,30 \\
Interaction & $-0,42$ & - & - \\
\hline
\end{tabular}

Table 4. Effect value of each factor and of both interaction to value of rate release (flux)

\begin{tabular}{cccc}
\hline Factors & Effect & $\begin{array}{c}\text { p-value } \\
\text { ANOVA }\end{array}$ & $\begin{array}{c}\text { Contribution } \\
(\%)\end{array}$ \\
\hline Carbopol 940 & $-9,19$ & 0,0006 & 15,32 \\
Asam oleat & $-20,91$ & $<0,0001$ & 79,24 \\
interaksi & $-2,71$ & 0,1452 & 1,34 \\
\hline
\end{tabular}

Table 5. Correlation of actual and coded values of levels

\begin{tabular}{cccc}
\hline Level & Coded & \multicolumn{2}{c}{ Actual factor } \\
\cline { 3 - 4 } factor & factor & Carbopol 940 (X1) & Oleic acid (X2) \\
\hline High level & -1 & $0,8 \%$ & $5 \%$ \\
Low level & +1 & $1,3 \%$ & $20 \%$ \\
\hline
\end{tabular}




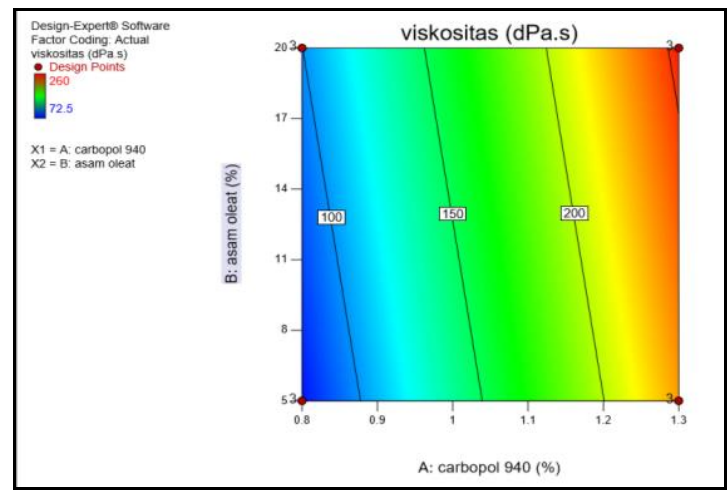

Figure 1. Contour plot $2 \mathrm{D}$ showing the factor to viscosity response

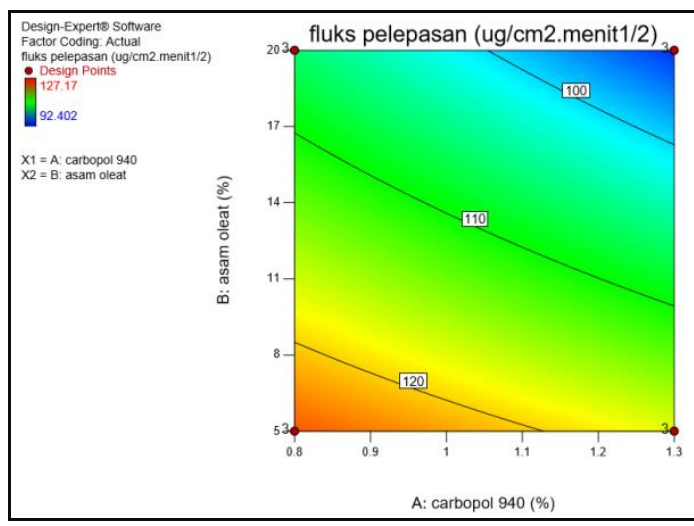

Figure 2. Contour plot 2D showing the factor to rate release response

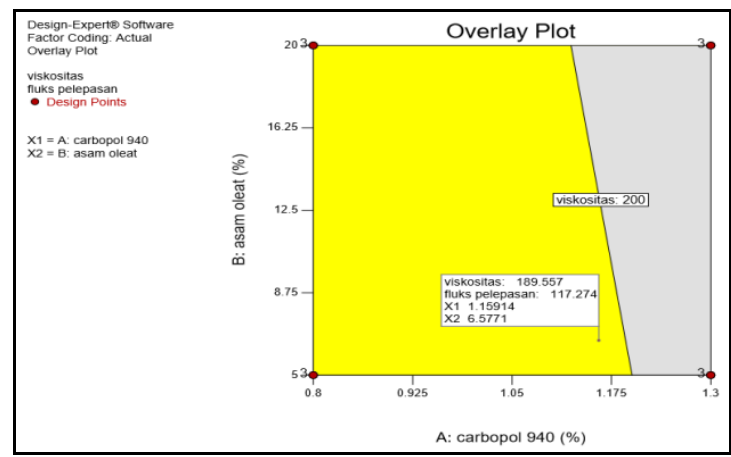

Figure 3. Overlay plot optimum formula 